\title{
Ferula halophila Ekstraktının Galleria mellonella L. (Lepidoptera: Pyralidae)' nın Protein Miktarı ve Katalaz Aktivitesi Üzerine Etkileri
}

\author{
Rahile ÖZTÜRK \\ Sorumlu yazar: rozturk@selcuk.edu.tr
}

Selçuk Üniversitesi Fen Fakültesi, Biyoloji Bölümü, KONYA

Orcid No: 0000-0001-7976-1790 / rozturk@selcuk.edu.tr

\begin{abstract}
Öz: Lepidoptera ordosuna ait olan Galleria mellonella L., arıc1lıta peteklere zarar veren, ekonomik yönden zararlı, holometabol bir böcek türüdür. Büyük balmumu güvesi olarak bilinen bu türün larvaları, polen ve petekle beslenerek arı kovanlarına büyük zarar verir. G. mellonella, kısa hayat devresine sahip olması ve yüksek verimliliği ile ve ayrıca çeşitli yapay besinlerde iyi gelişebilmesi nedeniyle biyolojik ve kimyasal mücadele çalışmaları için önemli bir böcek türü olarak kabul edilmektedir. Tuz çakşırı ismiyle bilinen Ferula halophila Peşmen; maydanozgiller (Apiaceae) familyasına ait, çok yıllık, 60- $90 \mathrm{~cm}$ uzunluğunda ve Tuz Gölü civarında yayılış gösteren endemik bir bitkidir. Bu tür, halofit bir bitki olup bu bitkinin tehlike kategorisi VU (zarar görebilir)'dur. $\mathrm{Bu}$ çalışmada, laboratuvar şartlarında yetiştirilen G. mellonella'nın larval evresinde uygulanan $F$. halophila ekstraktının, böceğin katalaz enzim aktivitesi üzerine etkileri araştırılmıştır. Deney grupları için, stok kültürlerden elde edilen yumurtalar, farklı dozlarda (20, 40 ve 60 ppm) bitki ekstraktı karıştırılmış besin içine bırakılmış ve yumurtadan çıkan larvaların bu besinle beslenmeleri sağlanmıştır. Aynı bitki ekstrakt oranlarında, homojenattaki protein miktarlarındaki değişimleri incelemek için böcekten protein izolasyonu gerçekleştirilmiştir. Homojenatlardaki toplam protein miktarı Bradford metodu ile belirlenmiş ve ekstraktlara SDS- PAGE analizi yapılarak protein profilleri çıkartılmıştır. Elde edilen ekstraktlar, enzim aktivite analizleri için kullanılmıştır. Çalışmada, özellikle savunma mekanizmasında etkili olan katalaz enzim aktivitesi ölçülmüştür. Sonuçlar incelendiğinde; 20, 40 ve 60 ppm ekstrakt içeren besinle beslenen larvalarda, F. halophila ekstraktının konsantrasyonundaki artışa bağlı olarak katalaz aktivitesinin de arttığı tespit edilmiştir. Son yıllarda zararlı böceklerle mücadelede kullanılan pestisitlerin, böcek fizyolojisi ve biyokimyası üzerine etki mekanizmaları araştırılmaktadır. Bu çalışmada, bazı türlerinin afrodizyak etkisi de bilinen Ferula cinsine ait $F$. halophila'nın böcek metabolizmasına etkisinin incelenmesinde G. mellonella model bir canlı olarak kullanılmıştır.
\end{abstract}

Anahtar Kelimeler: Ferula halophila, Galleria mellonella, Katalaz, Protein

\section{The Effects of Ferula halophila Extract on the Protein Amount and Catalase Activity of Galleria mellonella L. (Lepidoptera: Pyralidae)}

\footnotetext{
Abstract: Lepidoptera orders belonging to the Galleria mellonella L., damaging honeycomb in beekeeping, is an insect pest holometabol economically. Larvae of this species known as the great wax moth, pollen and great harm to the feeding combs, beehives. G. mellonella, and to have a short life cycle and high efficiency, and also to be recognized as an important insect species because it can grow well on a variety of biological and chemical control studies on artificial food. Salt flint known as Ferula halophila Peşmen; Apiaceae belonging to the family, many years, is an endemic plants spread around 60-90 cm in length and Salt Lake. This species of this plant is a plant halophytes danger category VU (damage), respectively. In this study, grown in laboratory conditions $G$. mellonella 's applied to the larval extracts of $F$. halophila, its effects on catalase aktivity were investigated. For experimental groups, egg extracts from stock cultures were plunged into mixed nutrient at different doses (20, 40 and $60 \mathrm{ppm})$ and eggs were fed to the larvae. At the same plant extract ratios, bovine protein isolation was performed to investigate changes in homogeneous protein quantities. The total amount of protein in the homogenates was determined by the Bradford method and protein profiles were extracted by SDSPAGE analysis of the extracts. The obtained extracts were used for enzyme activity analysis. Catalase enzyme activity, which is particularly effective in the defense mechanism, has been measured in the study. When the results are examined; It has been found that catalase activity is also increased in larvae fed with food containing 20, 40 and $60 \mathrm{ppm}$ extract due to the increase in the concentration of $F$. halophila extract. Last year in pesticides used in pest control, insect physiology and biochemistry on the mechanisms of action are being investigated. In
} 
this study, the aphrodisiac effect of some species of the genus known Ferula F. halophila' s to assess the effects of insect physiology G. mellonella was used as a live model.

Keywords: Ferula halophila, Galleria mellonella, Catalase, Protein

\section{Giriş}

Ürünlerde verimliliği olumsuz yönde etkileyen zararlıları yok etmek için pestisit adı verilen zehirli kimyasal maddeler yaygın olarak kullanılmaktadır. Bilinçsiz ve kontrolsüz pestisit kullanımı hedef canlıların yanı sıra hedef alınmayan canlıları da etkilemektedir. Asıl amaçları hastalık ve zararlıları yok etmek olan pestisitler, sürekli kullanıldıklarında hem ekolojik hem de ekonomik açıdan büyük sorunlara neden olmaktadır. $\mathrm{Bu}$ nedenle de pestisit uygulanacak türün biyoloji ve fizyolojisinin iyi bilinmesi ve doğaya zarar vermeden zararlı böceklerin kontrol altına alınması için uygun pestisit konsantrasyonunun belirlenmesi gerekmektedir.

Son yıllarda zararlı böceklerle mücadelede kullanılan pestisitlerin böcek fizyolojisi ve biyokimyası üzerine etki mekanizması araştırılmaktadır. Böceklerin, pestisitlere maruz kalması sonucu genom, protein, lipit ve karbohidrat metabolizmalarında önemli etkiler gözlenmiştir. Bununla birlikte böceklere uygulanan zararlı kimyasallar, sentezlenen proteinlerin yapı ve miktarı üzerinde de etkilidir. Özellikle sentezlenen enzimlerin aktiviteleri artmakta ya da azalmaktadır (Uçkan ve ark., 2008).
Pestisitlerin protein yapılarına etkisi direk olarak enzim aktivitesi ile ilişkilidir. Enzimler ise biyokimyasal mekanizmaların en önemli elemanlarıdır.

Doğada kimyasal kirliliğe yol açan, toprakta, suda, meyvelerde, sebzelerde ve diğer besin maddelerinde uzun süre bozulmadan kalan ve besin zinciri yoluyla insanlara kadar ulaşabilen pestisitlerin alerjik, karsinojenik, mutajenik ve teratojenik etkilerinin olduğu, çeşitli canlılarla yapılan çalışmalarla gösterilmiştir (Vural, 1984; Asal, 1985; Uçkan ve ark., 2008).

Pestisitler, böcekleri öldüren (insektisitler), mantarlar üzerine etkili olan (fungusitler), bakteriler üzerine ekili olan (bakterisitler), yabanc1 otlarla mücadelede kullanılan (herbisitler), nematotları öldüren (nematositler) ve kuşları öldüren (avisitler) olmak üzere sınıflandırılabilir (Öncüer, 2004). Zararlı böcek türlerine karşı kullanılan insektisitler böceklerde metabolizma anormallikleri, enzim aktiviteleri değişiklikleri, davranış bozuklukları, beslenme alışkanlıkları değişiklikleri, üreme anormallikleri, parazitleme ve parazit çıkışı anormalliklerine sebep olmaktadırlar (Haynes, 1988; Dursun, 2009). 
Pestisitlerin böceklerin fizyolojik, biyokimyasal ve moleküler özellikleri üzerine etkileri ile ilgili pek çok çalışma yapılmıştır. Nath ve ark. (1997) organofosforlu insektisitlerin Bombyx mori'de hemolenf protein miktarını azalttığını bildirmişlerdir. Shin ve ark. (2001) G. mellonella'da bir ağır metal olan kadmiyumun total lipid ve yağ asitleri üzerine etkilerini araştırmış ve kadmiyumun total lipit bileşenlerini önemli ölçüde azalttığını tespit etmişlerdir. Etebari ve ark. (2007) priproksifen uygulanmış ipek böceği larvalarında hemolenfteki biyokimyasal değişiklikleri incelemişlerdir. Bu çalışmanın sonucunda total protein miktarında, alanin aminotransferaz enzimi ve alkalin fosfatazın aktivitelerinde azalma meydana geldiğ görülmüştür. Yine, farklı böcek türlerini kimyasallara maruz birakarak yapılan daha önceki çalışmalarda; ergin öncesi gelişim süresinin, eşey oranının, ergin ömür uzunluğunun, yumurta veriminin, puplaşma ve ölüm oranının, protein, lipid ve glikojen miktarlarının, malondialdehid (MDA) miktarının, bazı enzimlerin aktivitelerinin ve diapoz süresinin önemli ölçüde etkilendiği tespit edilmiştir (Şahin, 2010; Sak ve Uçkan, 2009; Uçkan ve ark., 2008; Sezer ve Özalp, 2011).

Lepidoptera takımına ait zararlı türlerin yapay besinler ile kültüre alınması, ekoloji ve fizyolojilerinin yanında bunların farklı evrelerindeki bazı metabolik olaylarının moleküler düzeyde incelenmesine de olanak sağlar (Mandato ve ark., 1997; Pohlon ve Badwin, 2001; Büyükgüzel ve Yazgan, 2002; Tunaz ve ark., 2003). Böylece geliştirilen yeni insektisitlerin arazi uygulamasından önce laboratuvar şartlarında böcek üzerindeki etkileri araştırılmış olmaktadır.

Lepidoptera ordosuna ait olan Galleria mellonella Linneaus 1758, arıcılıkta peteklere zarar veren, ekonomik yönden zararlı bir türdür. Büyük balmumu güvesinin larvaları, polen ve petekle beslenerek arı kovanlarına büyük zarar verirler. Larvalar, yumurtadan çıktıktan sonra 8 evre geçirirler ve son iki evrede maksimum büyüklüğe ulaşırlar. Olgunlaşan son evre larvaları, pup evresine geçer ve puplardan da ergin bireyler (güveler) oluşur. Ergin güveler, yumurtalarını kovanlarda bal arılarının ulaşamayacağı ahşap kısımlardaki çatlaklara bırakırlar. Genç larvalar petekler içinde oyuklar açarak bal ve petekleri beslenmek amacıyla kullanırlar. Yaşlı larvalar ise ördükleri ağlarla petekleri birbirine yapıştırarak tamamen yerler.

G. mellonella'nın laboratuvar şartlarında kültürü kolaylıkla yapılabilmektedir ve hem pupları hem de larvaları bazı parozitoid türlerin laboratuvarda çoğaltılabilmesi için konak olarak kullanılmaktadır (Wiedenmann ve ark., 1992; Gupta ve ark., 1996; Büyükgüzel, 2001). 
Böceklerde protein, karbonhidrat ve lipid metabolizması pek çok hayatsal fonksiyonun gerçekleşmesinde önemli bir etkiye sahiptir. $\mathrm{Bu}$ maddelerin miktarına, cinsiyet (Aktümsek, 1996), yaş (Şeker ve Yanıkoğlu, 1999), diyapoz (Pullin, 1992), fotoperiyot (El- Aw, 2003), besin (Yanıkoğlu, 1985; Olson ve ark., 2000), sicaklık (Izumi ve ark., 2005) ve insektisit uygulamaları gibi pek çok faktör etki etmektedir.

Tuz çakşırı ismiyle bilinen Ferula halophila Peşmen; maydanozgiller (Apiaceae) familyasından ve Tuz Gölü civarında yayılış gösteren endemik bir bitkidir. Bu bitkinin tehlike kategorisi VU (zarar görebilir)'dur.

In vivo çalışmalar, deneyin niteliği ve sonuçların güvenilirliği için model organizmalarla yürütülmektedir. Model organizma tercihinde kısa zamanda ve çok sayıda üretilebilmeleri, bakım maliyetleri, uygulamada kolaylıkları (büyüklük, yaşam devamlılığı için gereken şartlar v.b.) ve etik durumu gibi faktörler göz önünde bulundurulmaktadır. Bu şartları sağlayan ve omurgalı model organizmalarla benzer deney sonuçları elde edilebilen omurgasız model organizmaların kullanımı bu nedenlerle son yıllarda giderek artış göstermektedir. Yaygın olarak omurgasız model organizma olarak kullanılan türlerden en öne çıkanı G. mellonella'dır (BarillasMury ve ark., 2000; Champion ve ark.,
2009; Junqueira, 2012; Martinez ve ark., 2017; Sigle ve Hillyer, 2018). Çalışmalarda G. mellonella'nın giderek artan oranda tercih edilmesinin nedeni, memelilerin doğuştan gelen bağışıklık yanıtlarına yapısal ve işlevsel olarak benzer bir bağışıklık sisteminin bulunması (Vilmos ve Kurucz, 1998; Cutuli ve ark., 2019), insan vücut sıcaklığında $\left(37^{\circ} \mathrm{C}\right)$ hayatta kalması ve uygulamalarda memeli model organizmalarla benzer sonuçlar elde edilmesidir (Sheehan ve ark., 2018). Ayrıca, model organizma G. mellonella'nın enzimleri üzerine, çeşitli doğal veya kimyasal maddelerin etkilerini inceleyen çok sayıda çalışma bulunmaktadır. Örneğin; Dere ve ark. (2015) yaptıkları bir çalışmada, azadirachtinin G. mellonella'nın antioksidan enzimleri üzerine etkilerini inceledikleri çalışmada, doza bağlı olarak bu türde oksidatif stresi arttırdığını tespit etmişlerdir. Zorlu ve ark. (2018) ise, diete dahil olan titanyum dioksit nanopatriküllerinin, doza bağlı olarak toksik etkisi olduğu ve düşük konsantrasyonda oksidatif strese karşı dayanıklılığı arttırdığını bulmuşlardır.

Son y1llarda zararlı böceklerle mücadelede kullanılan pestisitlerin, böcek fizyolojisi ve biyokimyası üzerine etki mekanizmaları araştırılmaktadır. $\mathrm{Bu}$ çalışmada, bazı türlerinin afrodizyak etkisi de bilinen Ferula cinsine ait $F$. halophila'nın böcek metabolizmasına etkisinin incelenmesinde G. mellonella 
model bir canlı olarak kullanılmıştır. Sonuç olarak; çalışmamız için seçtiğimiz model organizma G. mellonella'nın bazı enzim parametreleri üzerinden elde edilecek olan verilerin, diğer canlıların enzim etkileşimlerinin anlaşılması için temel oluşturması hedeflenmiştir.

\section{Materyal ve Metot}

G. mellonella stok kültürü Bronskill (1961)'den yararlanılarak hazırlanmış yarı sentetik besinde yetiştirilmiştir. Kavanozlara birkaç adet ergin koyularak $28 \pm 11^{\circ} \mathrm{C}, \% 60 \pm 5$ bağıl nem ve karanlık şartlarında gelişmeye bırakılarak stok kültürler elde edilmiştir. Deney grupları için, stok kültürlerden elde edilen yumurtalar, farklı oranlarda $(20,40$ ve $60 \mathrm{ppm}) \quad F$. halophila ekstraktı karıştırılmış besin içine bırakıldıktan sonra, meydana gelen larvaların bu besinle beslenmeleri sağlanmış ve ekstraktı bünyelerine almış olan son evre larvalar enzim aktivitelerinin belirlenmesi için aşağıdaki işlemlere tabi tutulmuşlardır. Kontrol grubu içinde aynı işlemler, ekstrakt ilave edilmemiş besin ile beslenen larvalara uygulanmıştır. Hem kontrol grubu hem de deney grupları üç tekrarlı olarak çalışılmıştır.

\subsection{Böceklerin homojenizasyonu}

Böcekler 1M fosfat tamponu ( $\mathrm{pH} 7.4)$ içerisinde $24000 \mathrm{rpm} / \mathrm{dk}$ 'da homojenize edilmiştir. Homojenat 10000 rpm'de 30 dakika santrifüj edilmiştir. Bu işlemden sonra elde edilen supernatant; enzim aktivitesi tayininde ve protein miktarının belirlenmesinde, dipteki pellet ve yaklaşı $0.2 \mathrm{ml}$ süpernatant ise glikojen miktarının belirlenmesinde kullanılmıştır.

\subsection{Protein izolasyonları}

$0.2 \mathrm{M}$ fosfat tamponu (pH: 6,8) gerekli miktarlarda alınarak hazırlanmış ve buzdolabında $+4^{\circ} \mathrm{C}^{\prime}$ de inkübe edilmiştir. Deney aşaması şu basamaklardan oluşmaktadır:

1. $0.1 \mathrm{~g}$ böcek tartılmış ve havanda sıvı azot ile ezilmiştir.

2. Ezilen kısım tüp içerisine alınmış ve üzerine mikropipet yardımıyla $500 \mathrm{ml}$ fosfat tamponu ilave edilmiştir.

3. Tüpler vortexlenerek karıştırılmış ve $70{ }^{\circ} \mathrm{C}$ 'de 15 dakika istıılmıştır.

4. Isıttma işleminden sonra tüpler 4 ${ }^{\circ} \mathrm{C}$ 'de 10 dakika $6500 \mathrm{rpm}$ hızda santrifüj edilmiştir.

5. Süpernatant kısımlar ayrı tüplere aktarılmış ve üzerine laboratuvarda hazırlanan boyama çözeltisi ilave edilmiştir.

6. Tüpler tekrar $100^{\circ} \mathrm{C}$ 'de 5 dakika 1sitılmıştır.

7. Tüpler santrifüj edilmiş ve süpernatant kısımlar alınarak jele yüklenmiştir.

\subsection{Protein tayini}

Protein miktarının tayininde Bradford (1976) tarafindan gösterilen yöntem kullanılmıştır. 


\section{$\underline{\text { Katalaz aktivite tayini }}$}

Katalaz (CAT) aktivitesinin tayini

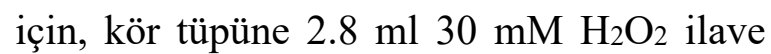
edilip, üzerine $50 \mathrm{mM}$ pH:7.4 $0.2 \mathrm{ml}$ fosfat tamponu eklendikten sonra seri bir şekilde çalkalanarak spektrofotometrede $240 \mathrm{~nm}$ 'de 30 saniye aralıklarla iki kez okunmuştur. Örnek için kullanılan tüpe yine aynı miktar $30 \mathrm{mM} \mathrm{H} \mathrm{H}_{2} \mathrm{O}_{2}$ konup, üzerine $0.2 \mathrm{ml}$ örnek eklenerek hızlı bir şekilde çalkalanmış ve 240 nm'de absorbansları okunmuştur. İlk okuma A1, ikinci okuma A2 olarak adlandırılmıştır (Aydemir ve Kuru, 2003).

$$
\begin{aligned}
& U=(2.3 / \Delta x) \times \log (A 1 / A 2) \\
& \mathrm{U}=\left(\begin{array}{llll}
2.3 / & 30
\end{array}\right) \quad \mathrm{x} \quad \log (\mathrm{A} 1 / \mathrm{A} 2)
\end{aligned}
$$

Formülü ile hesaplanarak katalaz aktivitesi $\mathrm{U} / \mathrm{mg}$ protein olarak ifade edilmiştir.

\section{Araştırma Sonuçları}

\subsection{Protein izolasyon ve tayini}

$\mathrm{Bu}$ çalışmada gerçekleştirilen protein izolasyon metodlarından sonra, son evre larvalardaki protein miktarları Tablo 1'de verilmiştir. Buna göre 3 farklı metodla 20, 40 ve 60 ppm bitki ekstraktı ilavesiyle $G$. mellonella

larvalarının

protein miktarlarındaki değişim incelenmiştir. Metod olarak en fazla protein izolasyonu Metod 2 (TCA metodu) ile gerçekleştirilmiştir. Protein miktarları Bradford analizi ile çizilen BSA kalibrasyon denkleminden hesaplanarak bulunmuştur.

Elde edilen protein ekstraktlarından 20 ppm ekstrakt uygulamasinın gerçekleştirildiği protein ekstraktları SDSPAGE jeline yüklenerek en düzgün band1 veren izolasyon metodu belirlenmiştir. Böylece protein bantlarının en düzgün olduğu metod ile enzim aktivitesi belirlenmiştir. Her ne kadar protein miktarının yüksek olduğu metod önemli olsada enzim aktivitesi göreceli olarak protein yapılarının bozunmadığı en uygun metodla belirlenmeye çalışılmıştır. Buna göre Şekil 1'de verilen jel görüntüsüne bakıldığında en uygun metodun 3 olduğu bulunmuş ve enzim aktivite tayini de bu metodla elde edilen ekstraktlarla gerçekleştirilmiştir.

\begin{tabular}{|c|c|c|c|}
\hline & Metod 1, mg/g & Metod 2- TCA, mg/g & Metod 3, mg/g \\
\hline Kontrol & 34.64 & 45.93 & 39.37 \\
\hline 20 ppm & 36.76 & 46.99 & 42.11 \\
\hline 40 ppm & 38.42 & 52.75 & 45.82 \\
\hline 60 ppm & 41.35 & 56.53 & 48.77 \\
\hline
\end{tabular}

Tablo 1. Farklı metodlarla protein izolasyonundan elde edilen protein miktarları 


\section{$\begin{array}{llll}M & 1 & 2 & 3\end{array}$}

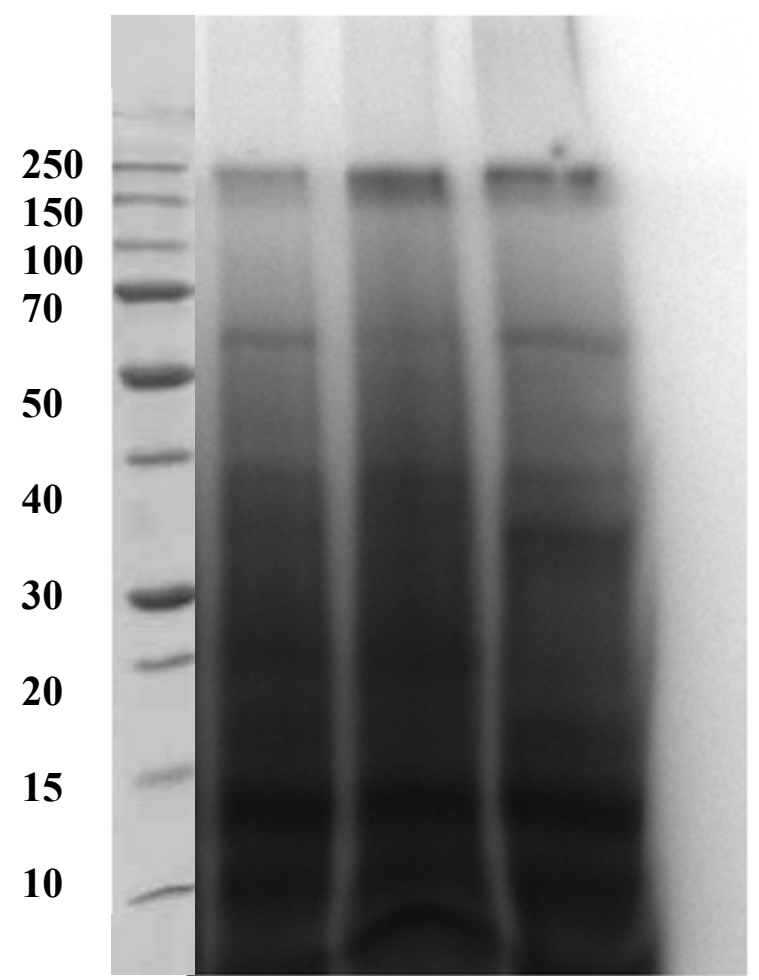

Şekil 1. Protokol 2' ye iliş̧in SDS-PAGE görüntüsü. M- Marker; 1- Metod 1; 2- Metod 2; 3- Metod 3.

\subsection{Enzim aktivitesi}

Katalaz (CAT) aktivitesi 20, 40 ve

60 ppm $F$. halophila ekstraktı uygulaması sonucu elde edilen ekstraktlara hidrojen peroksit ilave edilerek gerçekleştirilmiştir. Bununla birlikte aynı ekstraktta Metod 3 kullanılarak protein miktarları tayin edilmiş ve aktiviteler gram doku başına hesaplanmıştır. Besindeki extrakt miktarı arttıkça larvalardaki CAT aktivitesi de artmıştır (Tablo 2).

Tablo 2. F. halophila ekstraktı uygulaması sonucu elde edilen CAT aktivitesi ve protein izolasyonundan elde edilen protein miktarları

\begin{tabular}{|l|c|c|c|c|}
\hline & \multicolumn{1}{|c|}{ Kontrol } & $\mathbf{2 0} \mathrm{ppm}$ & $\mathbf{4 0} \mathrm{ppm}$ & $\mathbf{6 0} \mathrm{ppm}$ \\
\hline CAT aktivitesi (U/mL) & 0.88 & 2.06 & 2.11 & 2.53 \\
\hline Protein mg/g doku & 38.15 & 42.33 & 45.93 & 48.13 \\
\hline
\end{tabular}

\section{Tartışma}

Kimyasal mücadelede kullanılan

yeni insektisitlerin böcekler üzerindeki etkilerinin tespit edilmesinde yaşama, gelişme, ömür uzunluğu ve yumurta verimi gibi biyolojik etkinlik parametrelerinin yanında biyokimyasal ve fizyolojik tepki mekanizmalarının da iyi bilinmesi gerekmektedir.

Arıcılığın gelişmesini engelleyen en önemli etkenlerden birisi de arı hastalık ve 
zararlılarıdır. Bu yüzden arıcıların arılarda en çok görülen parazit ve hastalıkların belirti ve özellikleri ile bunlarla mücadele yöntemleri hakkında bilgi sahibi olmaları gerekir. Bilinçsizce ve yanlış yapılacak uygulamalar hem ekonomik kayıplara hem de hastalığın sağlam kolonilere yayılmasına neden olacaktır. Hastalıklarla mücadelenin zamanında, uygun ilaçla ve uygun dozda yapılmasına özen gösterilmelidir. Gereksiz ve aşırı kullanılan ilaçların bal ve balmumunda kalıntı birakarak insan sağlığını olumsuz etkileyeceği unutulmamalıdır (Tutkun ve Boşgelmez, 2003).

Dünyada arıcılık yapılan hemen her bölgeye yayılmış olan büyük balmumu güvesi, bal arısının en önemli zararlılarından biridir. G. mellonella'nın larvaları; balmumu, bal ve depolanmış polenler üzerinde beslenerek ağır ekonomik kayıplara neden olur. Sağliklı aktif kolonilerde mum güvesi zararı, işçi arılar tarafından etkili bir şekilde kontrol edilmekte ise de; anasız kolonilerde, pestisit veya hastalıklara maruz kalarak zayıflamış kolonilerde, büyük kayıplar meydana gelmektedir. En ağır kayıplar ise kış ayları süresince depolanmış peteklerde görülmektedir (Tutkun ve Boşgelmez, 2003).

\section{G. mellonella'ya karşı yapılan} kontrol çalışmalarında Dünya'da ve ülkemizde; kimyasal maddeler (paradiklorbenzen, etilen dibromid, kükürtdioksit, asetik asit, kalsiyum siyanid, metilbromid), fiziksel uygulamalar (1sitma, soğutma) ve biyolojik uygulamalar (Bacillus thuringiensis bakterisi) gibi yöntemler kullanılmaktadır.

Günümüzde kimyasal maddelerin oluşturduğu bir okyanus içinde yaşamaktayız. Bilinçsiz uygulanan kimyasal mücadele ile kanserojen, teratojen ve mutajen olan kimyasalların bu okyanustaki birikimi giderek artmaktadır (Shulka ve ark., 2002). Denetimsiz ve düzensiz kullanım, zaman içinde zararlının direnç kazanmasına sebep olarak, dozun her geçen gün daha da arttırılmasına neden olmaktadır (Soderlund ve Knipple, 1999). Buna bağlı olarak hem çevre kirlenmesi hızlanmakta hem de ekonomik kayıp artmaktadır.

Böceklerde endokrin sistem, çevresel uyarılara karşı kimyasal bir düzenleyicidir. $\mathrm{Bu}$ yüzden böceklerin dişarıdan gelen streslere karşı gösterdikleri tepki omurgalı hayvanların verdiği tepkiye çok benzemektedir.

$\mathrm{Bu}$ çalışmada Ferula halophila ekstraktının, canlı metabolizmasına etkisinin incelenmesinde $G$. mellonella model bir canlı olarak kullanılmıştır. Bu çalışmadan elde edilen veriler kullanılarak kimyasal mücadelede kullanılan diğer pestisitlerin canlı metabolizmasına etkisinin araştırılması için sonraki çalışmalara katkı sağlaması düşünülmüştür. Çünkü büyük balmumu güvesine karşı kullanılan kimyasal 
maddelerden birçoğu balmumu ve balda kalıntı bırakarak ürünün pazar şansını düşürmekte veya yok etmektedir (Tutkun ve Boşgelmez, 2003). Bu açıdan günümüzde, zararlıya karşı kullanılan ilaçların kalıntı durumu ve uygulanabilme kolaylığı göz önüne alınarak yeni arayışlara yönelmek kaçınılmaz olmuştur. Dolayısıyla zararlı böceklere karşı kullanılacak kimyasalın çeşidinin, dozunun ve zamanlamasının seçimi, zararlının populasyon yoğunluğunu baskılamada önemli bir konu olarak karşımıza çıkmaktadır.

Glikoz oksidaz enzimi bir oksidoredüktaz olup, glikozu hidrojen peroksit ve D- glukono- laktona dönüştürür. $\mathrm{Bu}$ oksidasyon reaksiyonu reaktif bir oksijen türü olan hidrojen peroksit oluşumunu katalizlediğinden, bu enzimatik reaksiyon bir antioksidan enzim olan katalaz enzimi ile doğrudan ilişkilidir. Çünkü katalaz, hidrojen peroksiti su ve oksijene parçalar. $\mathrm{Bu}$ çalışmada kullanılan bitkinin ekstraktı, böceğin diğer biyokimyasal mekanizmalarına bazı enzimlerin aktivitelerini değiştirmek suretiyle etki etmiştir. Glukoz oksidaz ve katalaz enzimlerinin biyokimyasal ilişkisi $G$. mellonella'nın bitki ekstraktı ile beslenmesi sonucu elde edilen bulgularda da doğrulanmıştır. Verilere göre besinde artan ekstrakt katalaz aktivitesini arttırmıştır. Katalazın glukoz oksidazla ilişkisi incelendiğinde larvalardaki glukoz oksidaz aktivitesinin de artması beklenmektedir. Nitekim 60 ppm vinclozolin ihtiva eden besinle beslenen larvaların, en yüksek glukoz oksidaz aktivitesine sahip olduğu gözlenmiştir. Bununla birlikte kontrol grubuyla karşılaştırıldığında glukozun glukoz oksidaz ile yıkımındaki artışın, larvadaki glikoz konsantrasyonunu düşürmesi beklenmektedir. $\mathrm{Bu}$ beklentiyi doğrulayan bir başka veri ise ekstrakt konsantrasyonu ile glikojen miktarı arasındaki ters orantıdır. Gerçekten de 60 ppm vinclozilinle beslenen larva, en düşük glikojen miktarına sahiptir. Bu da metabolik olarak glikojen katabolizmasında artış1 göstermektedir. Ksantin oksidaz ise yine bir oksidoredüktaz olup, reaktif oksijen türleri üretmektedir. Hipoksantinin ksantine oksidasyonunu katalizler ve daha sonra ksantinin de ürik aside oksidasyonunu katalizler. $\mathrm{Bu}$ da canlılarda pürinlerin katabolizmasında önemli bir rol oynadığını gösterir. Ancak larvalar, ne kadar bitki ekstraktı ile beslenirse beslensin kontrol grubuyla karşılaştırıldığında ksantin oksidaz aktivitesinde önemli bir değişme gözlenmemiştir. Dolayısı ile katalaz aktivitesindeki artışla ksantin oksidaz arasında herhangi bir ilişkinin olmadığ 1 tespit edilmiştir. Bununla birlikte bu çalışmada analizi yapılmayan diğer enzimlerin aktiviteleri belirlenemediğinden katalazın aktivitesindeki artış yalnızca glikoz oksidaz aktivitesi ile 
ilişkilendirilmiştir (Akman Gündüz ve çalışmalarla, bu eksikliğin giderileceği Gülel, 2010; Sezer ve Özalp, 2011; Özer, düşünülmektedir.

2011; Dursun, 2009). Gelecekte planlanan

\section{Kaynaklar}

Akman Gündüz E, Gülel A (2010). Protein, lipid, and glycogen levels in the parasitoid Bracon hebetor Say (Hymenoptera: Braconidae). Turk J Zool 34: 243-248.

Aktümsek A (1996) Parazitoid, Itoplectis maculator F. (Hymenoptera: Ichneumonidae)' un yağ asidi bileşimine konak ve eşey farklılığının etkisi. Turk J Zool 20: 7-10.

Asal S (1985). Bazı pestisitlerin mutajenik etkileri üzerine araştırmalar. Doğa Bilim Derg D2, 9(1): 72-78.

Aydemir T, Kuru K (2003). Purification and partial characterization of catalase from chicken erythrocytes and the effect of various inhibitors on enzyme activity. Turk $J$ Chem 27: 85-97.

Barillas- Mury C, Wizel B, Han YS (2000). Mosquito immune responses and malaria transmission: lessons from insect model systems and implications for vertebrate innate immunity and vaccine development. Insec Bioch and Mol Biol 30: 429-442.

Bradford M (1976). A rapid and sensitive method for the quantitation of microgram quantities of protein utilizing the principle of protein- dye binding. Anal Biochem 72: 248-254.

Bronskill J (1961). A cage to simplify the rearing of the greater wax moth, Galleria mellonella (Pyralidae). J Lep Soc 15(2): 102-104.

Büyükgüzel K (2001). Positive effects of some gyrase inhibitors on survival and development of Pimpla turionellae L. (Hymenoptera: Ichneumonidae) larvae reared on an artificial diet. J Econ Entomol 94: 21-26.

Büyükgüzel K, Yazgan Ş (2002). Effect of antimicrobial agents on the survival and development larvae of Pimpla turionellae L. (Hymenoptera: Ichneumonidae) reared on an artificial diet. Turk J Zool 26: 111-119.

Champion OL, Cooper IAM, James SL, Ford D, Karlyshev A, Wren BW, Duffield M, Oyston PCF, Titball RW (2009). Galleria mellonella as an alternative infection model for Yersinia pseudotuberculosis. Microbiol 155: 1516-1522.

Cutuli MA, Petronio Petronio G, Vergalito F, Magnifico I, Pietrangelo L, Venditti N, Di Marco R (2019). Galleria mellonella as a consolidated in vivo model hosts: New developments in antibacterial strategies and novel drug testing. Virulence 10(1): 527541 .

Dere B, Altuntaş H, Nurullahoğlu ZU (2015). Insecticidal and oxidative effects of azadirachtin on the model organism Galleria mellonella L. (Lepidoptera: Pyralidae). Arch of Ins Biochem and Physiol 89(3): 138-152.

Dursun O (2009). DDVP'nin (Dichlorvos) subletal dozlarının Galleria mellonella L.'nın protein, lipit ve karbohidrat düzeyine etkileri. Çukurova Ün., Fen Bil. Enst. Yüksek Lisans Tezi. 
El-Aw MA (2003). Effect of host plant, photoperiod, day time, developmental stage and sex on protein patterns and esterase inhibition heads of the cotton leafworm Spodoptera littoralis (Lepidoptera: Noctuidae). J Agri Res 48(1): 89-52.

Etebari K, Bizhannia AR, Sorati R, Matindoost L (2007). Biochemical changes in haemolymph of silkworm larva due to pyriproxyfen residue. Pestic Biochem Physiol 88: $14-19$.

Gupta P, Sloan A, Dillard CR, Frekovich SM (1996). Parasitism of factitious host, Galleria mellonella (Lepidoptera: Pyralidae) by an endoparasitoid: ovoposition and emergence of Microplitis croceipes (Hymenoptera: Braconidae). Fla Entomol 79(2): 221-229.

Haynes KF (1988). Sublethal effects of neurotoxic insecticides on insect behvior. Ann Rev Entomol 33: 149-168.

Izumi Y, Anniwaer K, Yoshida H, Sanoda S, Fujisaki K, Tsumuki H (2005). Comparison of cold hardiness and sugar between diapausing and nondiapausing pupae of the cotton bollworm, Helicoverpa armigera (Lepidoptera: Noctuidae). Physiol Entomol 30: 36-41.

Junqueira JC (2012). Galleria mellonella as a model host for human pathogens: Recent studies and new perspectives. Virulence 3(6): 474-476.

Mandato CA, Diehl-Jones WL, Moore SJ, Downer RGH (1997). The effects of eicosanoids biosynthesis inhibitors on prophenoloxidase activation, phagosytosis and cell spreading in Galleria mellonella. J Insect Physiol 43(1): 1-8.

Martinez MR, Wiedmann M, Ferguson M, Datta AR (2017). Assessment of Listeria monocytogenes virulence in the Galleria mellonella insect larvae model. PLoS ONE 12(9): e0184557.

Nath SB, Suresh A, Mahendra Varma B, Kumar RP (1997). Changes in protein metabolism in haemolymph and fat body of the silk worm, Bombyx mory L., in response to organophosporous insecticides toxicity. Ecotox Enviro Saf 36: 169-173.

Olson DM, Fadamiro H, Lundgren JG, Heimpel GE (2000). Effects of sugar feding on carbohydrate and lipid metabolism in a parasitoid wasp. Physiol Entomol 25: 17-25.

Öncüer C (2004). Tarımsal Zararlılarla Savaş Yöntemleri ve İlaçları. Genişletilmiş 5. Baskı. Adnan Menderes Üniversitesi Yayınları, No:19, 424s, Aydın.

Özer C (2011). Subletal dozlardaki diazinon'un Galleria mellonella L.' nın bazı biyokimyasal parametrelerine etkileri. Çukurova Ün. Fen Bil. Enst. Yüksek Lisans Tezi.

Pohlon E, Baldwin IT (2001). Artificial dies 'capture' the dynamics of jasmonate induced defenses in plants. Entomol Ex et App 100(1): 127-130.

Pullin A (1992). Diapause metabolism and changes in carbonhydrates related to cryprotection in Pieris brassicae. J Insect Physiol 38(5): 319-327.

Sak O, Uçkan F (2009). Cypermethrinin Galleria mellonella L. (Lepidoptera: Pyralidae)'nın puplaşma ve ölüm oranlarına etkisi. U Arı Derg 9(3): 88-96.

Sezer B, Özalp P (2011). Azadirachtinin Galleria mellonella larvalarında total glikojen miktarına etkisi. Ekoloji 20(81): 67-72.

Sheehan G, Garvey A, Croke M, Kavanagh K (2018). Innate humoral immune defences in mammals and insects: The same, with differences? Virulence 9(1): 1625-1639.

Shin BS, RI NC, Choong-Un L (2001). Effect of cadmium on total lipid content and fatty acids of the greater wax moth, Galleria mellonella. Korean J Ecol 24(6): 349-352. 
Shukla A, Zhang YH, Dubey P, Margrave JL, Shukla SS (2002). The role of sawdust in the removal of unwanted materials from water. J Hazard Mater 95(1-2): 137-152.

Sigle LT, Hillyer JF (2018). Mosquito hemocytes associate with circulatory structures that support intracardiac retrograde hemolymph flow. Front Physiol 9: 1187.

Soderlund DM, Knipple DC (1999). Knockdown resistance to DDT and pyrethroids in the house fly (Diptera: Muscidae): from genetic trait to molecular mechanism. Entomol Soc of Am 92(6): 909-915.

Şahin V (2010). Borik asitin laktoz ile birlikte Galleria mellonella L. (Lepidoptera: Pyralidae)'nın bazı biyolojik ve biyokimyasal parametrelerine etkisi. Zonguldak Karaelmas Ün., Fen Bil. Enst., Yüksek Lisans Tezi.

Şeker DA, Yanıkoğlu A (1999). Pimpla turionellae L. (Hymenoptera: Ichneumonidae)' nın açlık, beslenme, parazitleme ve yaşlılık durumlarında glikojen seviyesindeki değişmeler. Tr J of Zool 23: 289-296.

Tunaz H, Park Y, Büyükgüzel K, Bedick JC, Nor Aliza AR, Standey DW (2003). Eicosanoids in insect immunity: bacterial infection stimulates hemocytic phospholipase A2 activityin tobacco hornworms. Arch Insect Biochem 52(1): 1-6.

Tutkun E, Boşgelmez A (2003). Bal Arısı Zararlıları ve Hastalıkları Teşhis ve Tedavi Yöntemleri. Bizim Büro Basımevi, Ankara.

Uçkan F, Tüven A, Er A, Ergin E (2008). Effects of giberellic acid on biological parameters of the larval endoparasitoid Apanteles galleriae (Hymenoptera: Braconidae). Entomol Ann Soc Am 101(3): 593-597.

Vilmos P, Kurucz É (1998). Insect immunity: evolutionary roots of the mammalian innate immune system. Immunol Lett 62: 59-66.

Vural N (1984). Toksikoloji. Ankara Üniversitesi, Eczacılık Fakültesi Yayınları, No:56, sh 416, Ankara.

Yanıkoğlu A (1985). Schistocerca gregaria Forskal (Orthoptera: Acrididae) nimflerinin doğal ve sentetik besinde gelişimi sırasında glikojen miktarı tayini. Doğa Bilim Dergisi A2, 9(3): 582-592.

Wiedenmann RN, Smith JW, Darnell PO (1992). Laboratory rearing and biology of the parasite Cotesia flavipes (Hymenoptera: Braconidae) using Diatraea saccharalis (Lepidoptera: Pyralidae) as a host. Environ Entomol 21: 1160-1167.

Zorlu T, Nurullahoğlu ZU, Altuntaş H (2018). Influence of dietary titanium dioxide nanoparticles on the biology and antioxidant system of model insect, Galleria mellonella (L.) (Lepidoptera: Pyralidae). J of the Entomol Res Soc 20(3): 89-103. 